\title{
A VIAGEM DE CARONTE AO MUNDO DOS VIVOS: DESCOBERTAS E REVELAÇÓES
}

\author{
Maria Celeste Consolin Dezotti \\ Míriam Marta Guerra \\ FCL - UNESP - Araraquara
}

Resumo: 0 estudo das citações homéricas presentes no diálogo Caronte ou Os observadores, de Luciano de Samósata, mostra que a força da poesia homérica atua para além do plano humano, seduzindo até mesmo divindades de diferentes estatutos, como Caronte e Hermes. Muito mais que ornamento do discurso, as citaçôes bem como os modos pelos quais esses interlocutores se apropriam do discurso homérico refletem as diferentes intenções que governam suas respectivas falas.

Palavras-Chave: Citação, Apropriação, Paráfrase, Estilização.

Esta comunicação se faz como contribuição ao estudo das citações no texto de Luciano. Bompaire (Bompaire, 1958, p.384) lembra a predileção dos antigos por esse ornamento do discurso, ressaltando que na época imperial sua prática se intensifica. A citação de autores antigos se agrupa entre os recursos que, ao mesmo tempo em que proporcionam ao texto uma "poikilia", um colorido de expressão, refletem o preparo intelectual do escritor. Householder (Householder, 1941) fez um levantamento exaustivo das citaçōes em Luciano e observou que sua preferência por um autor ou outro está diretamente relacionada ao prestígio de que esses autores gozavam nas várias instâncias escolares pelas quais um aluno da época imperial passava. A esses dois estudos soma-se ainda 0 artigo de Anderson (Anderson, 1978), que confirma os resultados de Householder e vislumbra outras possibilidades de abordagem das citaçōes em Luciano. Um ponto que ele ressalta $e$ que nos interessa diretamente é a relação, ainda não muito explorada, entre o falante e o material literário que ele cita. Nesse sentido, a preocupação de Anderson se volta para função da citação enquanto elemento estrutural do texto de Luciano. É esse 0 objetivo deste trabalho: verificar em que medida, muito mais que elemento decorativo, a citação bem como o modo como ela é feita se ajustam na fala das personagens e passam a adquirir um papel na construção do significado do texto. No caso do diálogo Caronte, de que nos ocupamos, restringimos a análise às citações que Luciano faz do texto homérico, que, como o estudo de Householder indicou, tem predominância absoluta no conjunto das citações de Luciano.

0 diálogo Caronte tem como tema uma visita que o barqueiro do Hades faz ao mundo dos homens. Caronte abandona seu posto e sobe à terra para conhecer as tão cobiçadas vantagens da vida terrestre que os mortos abandonam em prantos.

Vê-se, pois, que o texto já se abre com uma situação inesperada: essa ausência de Caronte representa, sem dúvida, alguma alteração caótica na rotina do 
Hades, onde, sabe-se, as almas não param de chegar. E exatamente isso que deduz Hermes, com quem Caronte, todo sorridente, depara logo que pisa no mundo luminoso dos vivos. Trata-se de um feliz acaso, já que Hermes é seu parceiro na lide com os mortos. É a ele, pois, que Caronte se apresenta como "xenos" e the pede que seja seu guia nessa visita de reconhecimento. Constata-se, então, um importante elemento de inversão do mito. Caronte, até então piloto da barca dos mortos, entrega-se agora nas mãos de Hermes como passageiro em uma terra estranha, com caracteristicas físicas e valores sociais bem peculiares.

A diferença física básica é a luminosidade terrestre. Habituado à vida nas trevas infernais, Caronte é incapaz de enxergar na terra; a luz o atrapalha, ofusca seus olhos. É a mesma dificuldade que os mortos experimentam para enxergar nas trevas, quando passam da vida para a morte. Há, pois, uma necessidade de adaptação do olhar. Já no âmbito do relacionamento entre os homens, veremos que, entre outros valores, a competência discursiva ilustrada pela erudição é cobrada como valor fundamental, e nesse ponto o conhecimento de Homero é dado como imprescindivel. Ciente dessas exigências, Hermes, que tem trânsito livre por todas as esferas, deixa evidente, desde 0 início de seu diálogo com Caronte, a sua consciência de superioridade em relação ao barqueiro. Este, por sua vez, aguardará muito humildemente o momento exato de surpreender seu interlocutor e desfazer essa imagem falsa que ele havia construído a seu respeito.

0 primeiro passo de Hermes encontrar um lugar elevado que thes garanta o necessário distanciamento do observador em relação ao objeto observado. 0 ideal, segundo Hermes, é subirem em um monte elevado. 0 Olimpo seria perfeito, mas como Caronte não tem acesso a ele, o jeito é construir um bom mirante.

A lembrança do Olimpo traz a Hermes uma solução. Ele se lembra da ousada empresa de Oto e Efialtes, filhos de Aloeu, que tentaram, certa vez, construir uma escada até o céu onde pretendiam chegar para destronar Zeus. Para isso, arrancaram 0 monte Ossa de sua base e o colocaram sobre o Olimpo, e sobre 0 Ossa, o monte Pélion. Ao saber das intenções desses garotos, Zeus pune a ambos com a morte. É assim que narrava Homero.

A idéia de remover e empilhar montes assusta Caronte. Mas Hermes lembra-lhe que, para deuses, tal empresa não é impossivel e, em seguida, censura a falta de criatividade de Caronte, taxando-o de "muito pouco poético" (§ 4). 0 deus passa a falar em Homero e revela que o poeta lhes facilitara 0 acesso ao céu. É só usar corretamente os versos que os fatos que eles narram passam a realizar-se. Então Hermes recorta da Odisséia (XI, 315-16) um fragmento de poesia, um "épos" adequado para a situação e o enuncia como se fosse uma poção mágica:

"depois sobre o Ossa

o Pélion de moventes folhagens."

Imediatamente os montes se sobrepõem. Após esse espetáculo de magia poética, Hermes e Caronte sobem ao topo do mirante. Caronte observa o panorama mas não consegue enxergar com nitidez as cidades e os homens.

Hermes, então, aprimora a visão de Caronte recorrendo novamente a Homero. Após ter dado algumas instruções a Caronte ("quando eu disser os versos, pense que você não tem mais a vista fraca, mas que pode enxergar tudo 
nitidamente", §7), Hermes enuncia os seguintes versos, extraidos da llíada (, , 127-8):

"de teus olhos afastei a névoa que os encobria para reconheceres ora a um deus, ora a um homem."

Tais versos inserem a passagem em que Diomedes se prepara para lutar contra 0 troiano Estênelo. 0 herói pede proteção a Atena; a deusa ouve sua prece e Ihe aumenta o poder de visão, para que ele pudesse identificar, em meio à batalha, quem era humano e quem era divino.

A partir dal, o diálogo prossegue com as perguntas que Caronte dirige a Hermes na intenção de obter o máximo de informações a respeito da vida dos homens. E a primeira preocupação de Caronte é mostrar a Hermes que ele próprio não era indiferente aos poemas de Homero ("ameléteton tón Homérou"). Caronte também o conhece. Ele o transportara em sua barca, como morto, e durante a travessia o poeta não se lamentava como os demais mortos; ao contrário, comportava-se como verdadeiro sábio, passando o tempo a despejar rapsódias. Caronte também se deixou seduzir pelo encanto da poesia e até conseguiu guardar em sua memória muitas passagens da obra homérica. Ele também presenciou um espetáculo de magia poética, realizado pelo próprio Homero: enquanto narrava 0 episódio da Odisséia (V,290-6) em que Poseidon provoca tempestades, as águas do Aqueronte se revoltaram e por pouco o barco não emborcou.

0 que Caronte não sabia era em que consistia a eficiência mágica do verso homérico. Afinal, no Hades estava o poeta em pessoa a reproduzir seus próprios versos. Agora, na terra, ele viu que Hermes também conseguia o mesmo efeito com a enunciação de tais versos. Afinal, o poder mágico seria um atributo dos próprios versos ou de quem os enuncia?

Uma possível resposta para essa questão pode estar no modo como Hermes lida com as citações. Hermes faz, no diálogo com Caronte, quatro citações e todas de texto homérico. Dessas, duas são citações literais, que já comentamos; as outras duas são, ao contrário, paráfrases em que o deus resume, em prosa, o texto homérico. Examinemo-las.

Logo no início do diálogo, Hermes faz alusão ao episódio de Hefesto (IIIada, I,570-610), como justificativa para recusar-se em ser guia de Caronte. Como mensageiro de Zeus ele temia chegar atrasado no Olimpo e receber castigo semelhante ao que o pai dos deuses impusera a Hefesto. Diz Hermes: "eu temo que ele (...) me agarre pelo pé e também me precipite do umbral divino para que eu provoque risos ao servir de beber aos de uses, manquitolando."

No parágrafo 21, Hermes parafraseia a famosa passagem de Ulisses e as sereias (Odisséia,12,173ss), para ilustrar a que ponto os homens permitiram, por ignorância, que seus ouvidos ficassem surdos aos sábios conselhos dos verdeiros filosofos. Diz Hermes: "eles os encheram com tamanha quantidade de cera, como fez Ulisses com seus companheiros por temer que ouvissem as sereias."

Obsenva-se que Hermes cita em forma de paráfrase quando o texto homérico s6 the interessa enquanto conteúdo útil para a construção de um discurso argumentativo. Esse modo de citar contrasta com 0 anterior, em que Hermes pretende resgatar, dos versos homéricos, muito mais que seu conteúdo. Ao citar 
Homero literalmente, respeitando a autonomia poética de seus versos, Hermes está ciente de acionar a força mágica da poesia homérica, à qual até os deuses, apesar de deuses (o que é uma ironia!), precisam já recorrer. Para os deuses, pois, a poesia homérica é um "encantamento", uma "epodé", como diz Hermes (§7), da qual já não mais podem prescindir.

Vejamos agora como Caronte se comporta diante do texto homérico. São, ao todo, sete as citações que ele faz. E em todas elas constata-se que a preocupação do barqueiro é provar a Hermes o quanto ele é habilidoso no trato com o texto homérico, conseguindo não só parafraseá-lo como também, a partir dele, construir paródias e estilizações. Ele quer, enfim, que seu discurso seja respeitado. Posto isso, vejamos alguns exemplos de suas citações.

Uma certa intimidade de Caronte com o texto homérico aparece já no parágrafo 7, quando ele conta a Hermes como conheceu Homero. E para provar que soube ser um bom ouvinte, relata a Hermes, em forma de paráfrase, temperada com uma pitada de deboche, o já mencionado episódio de Poseidon. Diz Caronte: "ele começou a cantar um canto (...) que falava de como Poseidon juntou as nuvens e agitou o mar e lançou nele o seu tridente como se fosse uma colher de pau, levantando todos os furacóes e muitos outros elementos."

Mas Caronte exibe uma outra competência: ele sabe apropriar-se do texto homérico para formular enunciados adequados ao seu diálogo com Hermes. Esșa competência está mostrada nos parágrafos 8 e 9, em dois momentos em que Caronte pede a Hermes que the identifique duas pessoas que the chamaram a atenção.

Uma dessas pessoas é um famoso atleta que enfrenta um touro no estádio, sob os aplausos da multidão. Caronte solicita sua identidade por meio dos versos 225-227 do canto III, da IIIada, reestruturados pela paródia:

"Quem acaso é esse gordíssimo varão, alto e forte que excede os homens por sua cabeça e largos ombros?"

Comparado ao texto homérico, o texto de Caronte substitui a expressão "outro Aqueu" e "os Argivos" do texto homérico, pelas expressões "gordíssimo varão" ("pákhistos anér") e "os homens", respectivamente, numa clara intenção de depreciar a figura do atleta.

A habilidade de Caronte em fazer a exata adaptação do verso homérico ao contexto de sua própria fala pode ser comprovada quando confrontamos os dois contextos. Na llíada, Príamo e o conselho de anciãos observam, do alto da muralha, o combate entre gregos e troianos. Helena se aproxima e Príamo pede a ela que dê a identidade de alguns guerreiros aqueus, entre eles Ajax, cujo porte físico avantajado Príamo descreve com os referidos versos. No texto luciânico, Caronte e Hermes também se encontram em local elevado que favorece a visão panorâmica. $E$, como Príamo, Caronte repara em alguém extremamente corpulento que, ao contrário dos heróis, dispende sua força física em tauromaquias.

No parágrafo 9, Caronte dirige a Hermes outra pergunta. Baseado no verso 226, citado anteriormente, Caronte constrói o seguinte fragmento de hexâmetro: 
No parágrafo 14, Caronte sofistica a elaboração da pergunta e mistura prosa e verso. Mas atente-se para o detalhe: o verso é uma "contaminatio" de dois fragmentos de versos da Odisséia, extraidos de diferentes cantos:

"Mas quem é aquele, Hermes, de manto de púrpura abotoado, aquele de diadema, a quem o cozinheiro entrega 0 anel, após ter aberto 0 peixe

na ilha rodeada de água? Ele gloria-se de ser rei."

Esse verso combina parte do verso 50 do canto I, com a porção restante "ele gloria-se de ser um rei", que é parte do verso 67 do canto XVI. Vê-se, portanto, que, embora os componentes sejam homéricos, o verso citado por Caronte não existe como tal em Homero.

No parágrafo 22, Caronte dá mais uma demonstração de sua competência para construir hexâmetros à̀ moda homérica ("katà tòn Hómeron") . Ele consegue construir cinco versos, usando fórmulas épicas bastante conhecidas. Ao comentar a loucura humana, responsável pelo fato de os homens levarem a vida com tanta arrogância sem considerarem que, no final, a morte acabará igualando a todos, Caronte diz:

"morreu igualmente o homem insepulto e o sepulto uma so honra coube a Iros e ao chefe Agamenon. Igual a Tersittes é o fitho de Tétis, de formosos cabelos.

Todos são iguais, cabȩ̣as débeis de cadáveres, nus e ressequidos, no prado de asfódelos."

As partes sublinhadas nos versos acima correspondem a expressões formulares encontradas, respectivamente, na IIIada IX,320, IX,319 e IV,512, e na Odisséia X,536 e IX,539.

Mas a prova máxima da competência de Caronte em produzir estilizações homéricas encontra-se no parágrafo 19, onde ele constrói um símile que compara a vida humana com bolhas d'água. Embora o texto de Caronte seja em prosa, ele faz lembrar a passagem da Iliada ( VI, 145-149), em que Homero compara a raça humana com as folhas. Diz ele:

"Pelo menos eu quero Ihe dizer, Hermes, com que me parecem semelhantes os homens e a vida inteira deles. Acaso você já viu bolhas na água sob um jorro que irrompe violentamente? Estou falando daquelas borbulhas d'água, em que a espuma se acumula. Algumas são pequenas e, numa explosăo, logo se extinguem. Outras resistem mais. E quando outras avançam em direção a elas, elas se estufam $e$ aumentam de volume. Contudo, a seguir também explodem. Pois não pode ser de outro modo. Isso é a vida humana. Todos por um sopro estão inflados, uns mais, outros menos. Uns se mantêm por algum tempo e efêmero é o sopro; outros, tăo logo se formam, chegam ao fim. A todos, pois, é imperioso explodir." 
0 exame desses exemplos de citação mostra que os diferentes modos como cada personagem se apropria do texto de Homero são determinados pelos objetivos que cada uma delas pretende atingir com essa apropriação. Hermes cita Homero por meio de dois procedimentos diferentes: quando se trata de ostentar a Caronte a sua cultura, é suficiente parafrasear em prosa e por meio de resumos algumas passagens homéricas; mas quando se trata de realizar "maravilhas" para deixar seu interlocutor estupefato, Hermes precisa se apropriar do texto tal qual Homero 0 produzira, pois a seqüência de dátilos homéricos apresenta uma "dúnamis" de que Hermes depende para sustentar uma certa onipotência divina. 0 seu estatuto de deus já não mais the é bastante.

Caronte, por sua vez, enfrenta outro desafio: desqualificado, logo de início, pelo seu interlocutor, que o considerava um simplorio e inculto remador, Caronte se esforça por destruir tal imagem e se firmar, no diálogo, como interlocutor à altura de Hermes. Para tanto, a citação de Homero lhe surge como expediente imprescindivel. $E$, pelas mesmas razōes, explica-se a variedade de recursos, alguns bastante sofisticados, de que ele se serve para incorporar à sua fala o texto homérico. Não Ihe bastava repetir Homero literalmente. Mais que isso, ele se empenha em mostrar uma competência discursiva criadora, que implica, muitas vezes, em desarranjar e rearranjar o texto homérico de acordo com as solicitaçōes contextuais de sua própria fala. E que Caronte obteve sucesso em sua empresa demonstram as sucessivas sanções que Hermes faz às citações de seu interlocutor. Uma delas é bastante significativa, por reconhecer que Caronte não é um mero parasita do texto homérico; ao contrário, Hermes reconhece sua capacidade criadora, 0 que comprova que aquela primeira imagem construída a seu respeito já deixara de existir. Após o símile das bolhas, diz Hermes a Caronte: "Você, Caronte, construiu uma imagem em nada inferior à de Homero, que compara a raça humana ds folhas."

Resume: L'étude des citations homériques qu'on trouve dans le dialogue Charon ou Les observateurs, de Lucien de Samosate, montre que la puissance de la poésie homérique agit au-delà du plan humain, en seduisant même des dieux, tels Charon et Hermès. Plus qu'ornement du discours, les citations et les moyens par lesquels les interlocuteurs s'approprient le texte homérique reflètent les différentes intentions qui commandent leurs énonciations.

BIBLIOGRAFIA

ANDERSON, G. Patterns in Lucian's Quotations. Bulletin of the Institute of Classical Studies of the University of London, London, v. XXV, p. 97-100, 1978.

BOMPAIRE, J. Lucien Écrivain. Imitation et Création. Paris: E. de Boccard, 1958.

HOUSEHOLDER JR., F. W. Literary Quotation and Allusion in Lucian. New York: King's Crown Press, 1941.

LUCIANI. Contemplantes. In: Opera, tomus II, by M. D. Macleod. New York: Oxford University Press, 1974. 